\title{
Sweeney Todd: da Inglaterra para os EUA, um produto eloquente para refletir sobre a dinâmica urbana
}

\author{
Sweeney Todd: de Inglaterra a los EE.UU., \\ un producto elocuente para reflexionar sobre la dinámica urbana \\ Sweeney Todd: from England to the U.S., \\ a product eloquent to reflect about urban dynamics
}

\author{
Priscilla Oliveira Xavier ${ }^{1}$
}

Palavras chave:

Resumo:

Urbano

Cinema

Cultura

Este artigo pretende explorar as relações entre a sociedade e o espaço urbano, a partir de uma leitura sociológica do filme "Sweeney Todd: O Barbeiro Demoníaco da Rua Fleet”, adaptação de uma popular história inglesa, cuja direção é assinada por Tim Burton. $\mathrm{Na}$ análise são destacadas a trajetória social da história que inspirou o filme, enquanto um produto cultural, e as características da sociedade e da cidade impressos nessa história, como uma descrição de teor subjetivo de uma conjuntura na qual se instaurava uma nova ordem, inspirando novos hábitos e sensibilidades urbanas. Sobressaem na análise as alegorias dos temores, desconfortos e esperanças da sociedade enxertados em um produto cultural, o qual dialoga de modo peculiar, modificando conforme a conjuntura. 


\section{Resumen:}

Este artículo tiene como objetivo explorar la relación entre la sociedad y el espacio urbano, a partir de una lectura sociológica de la película "Sweeney Todd: El barbero diabólico de la calle Fleet", una adaptación de una historia popular Inglés, cuya dirección es firmado por Tim Burton. El análisis se destacan la trayectoria social de la historia que inspiró la película, como un producto cultural, y las características de la sociedad y de la ciudad de la historia como una descripción del contenido subjetivo de una situación de una nueva orden, inspirador de hábitos y sensibilidades urbanas. El análisis se muestran en las alegorías de los miedos, las esperanzas y las incomodidades de la sociedad injertadas en un producto cultural, que dialoga tan peculiar, cambiando a medida de la situación.
Palabras clave:

Urbano

Cine

Cultura

\section{Keywords:}

\section{Urban}

Film

Culture

\section{Abstract:}

The intention of this article is explore the relationship between society and urban space, from a sociological reading of the film "Sweeney Todd: The Demon Barber of Fleet Street," an adaptation of a popular English history, by Tim Burton. In this work are highlighted the social trajectory of the story that inspired the film, as a cultural product, and the characteristics of the society and the city printed in the story, as a description of subjective content, of a situation in which a new order apear, inspiring new habits and urban sensibilities. Show the allegories of the fears, hopes and discomforts of society into a cultural product, changing as conjuncture. 


\section{Sweeney Todd: da Inglaterra para os EUA, um produto eloquente para refletir sobre a dinâmica urbana}

\section{Introdução}

Londres, final do século XVIII. Sweeney Todd é um talentoso barbeiro, instalado na Rua Fleet, cuja clientela é formada por membros das classes abastadas da cidade. Misteriosamente, seus clientes começam a desaparecer. E para solucionar tal mistério, um detetive empreende uma minuciosa investigação até descobrir ser o barbeiro um sanguinolento assassino.

Esta é uma popular história ambientada no Reino Unido, na era Vitoriana. O periodo de reinado da Rainha Vitória, de 1837 a 1901, fora marcado por considerável prosperidade financeira, proporcionada pela expansão mundial do Império Britânico, pela consolidação da Revolução Industrial e pela intensificação de produções culturais voltados para uma classe média crescente, educada, esbanjadora e ociosa.

Na seara da produção cultural do período a literatura figura em destaque. Revelou escritores como George Eliot, Charles Dickens, Conan Doyle e Oscar Wilde, cujas prosas introduziam os leitores aos sabores e dissabores dos novos hábitos urbanos, muitas das vezes enquadrados a uma aura de soberba ou ao diletantismo.

Um outro gênero literário famoso e abundante no período, não menos condizentes ao espírito das classes abastadas porém de associação mais velada, foram as histórias com monstros como Frankstein, assassinatos em série e vampiros, inspirados em lobisomens e demais demônios lendários. A tônica dessa literatura ficcional era expressar as relações contraditórias entre o indivíduo e a sociedade. De mais característico dessa literatura estava o recurso linguístico de fazer analogia ao sangue como o elemento da contaminação, e as doenças e anomalias à degeneração do corpo social. O temor da contaminação era, por assim dizer, a metáfora da experiência urbana do período, uma vez que na adensada cidade era inevitável o convívio próximo entre indivíduos de classes sociais diferentes.

Nesse estilo literário tornou-se popular a história "O Barbeiro Demoníaco da Rua Fleet". Esta foi uma entre várias histórias de uma série vampiresca, escrita por Thomas Peckett Prest. Logo que publicada, em 1846, a história não alcançou grande êxito. Entre os motivos aventados para o desprestígio desta produção consta o fato de o autor escrever em quantidade e por encomenda, elementos esses que aos olhos da sociedade inglesa do período comprometiam a qualidade dos escritos. Posteriormente, em 1847, George Dibdin-Pitt, um ator britânico especializado em melodrama, adaptou a história da série de Thomas Peckett Prest para um musical, apresentado no Hoxton Theatre.

Neste primeiro momento de trajetória, a história "O Barbeiro Demoníaco da Rua Fleet”, embora já adaptada da literatura para o teatro, correspondia e dialogava com um tempo e espaço, com uma conjuntura específica. Cumpre antes de avançar esclarecer que neste trabalho toma-se como guia a perspectiva de que os produtos culturais possibilitam leituras de conjunturas específicas, apresentando tendências discursivas no âmbito político, econômico e social, todavia, enquanto produtos, não são estáticos, herméticos ou isentos da ação do tempo, do lugar e, enfim, da cultura que o absorve. Afinal, sua existência social está condicionada a estabeler diálogos e até se submeter a interpretações e adaptações. 
Da Europa para a América, em 1979, Stephen Sondheim adapta novamente a história para um musical, desta vez estrelado na Broadway. Nesta adaptação a saga sangrenta do barbeiro escapa da pura ganância e crueldade, tornando-se então motivada por uma questão passional. Se na Inglaterra a história é condizente com um período de transformações, gerando angústias e temores quanto as relações de classes, nos EUA o período é outro, todavia os temores não são tão diferentes. Coincide com o período inicial da hegemonia conservadora, conhecido como era Reagan. Os produtos culturais, especialmente o cinema, focavam os receios, as aspirações e as esperanças de uma sociedade cuja riqueza produzida pela classe média e classe trabalhadora era captada pelas classes altas. Cumpre ressaltar que o discursos de temor e suspeita instaurava-se entre a classe média e as classes trabalhadoras, numa relação agonística informada pelo pavor do rebaixamento na hierarquia social.

Sobre a expressiva produção de filmes de terror na década de 1980, lidando com os medos e as inseguranças da classe média norte americana, Kellner (2001) oferece possibilidades de leituras dos produtos culturais, mesmo se referindo especificamente ao cinema, afirma que;

Os filmes de terror constituem um gênero a tal ponto reacionário que responsabilizam as forças ocultas pela desintegração social e pela falta de controle da vida, desviando assim a atenção dos espectadores das fontes reais do sofrimento social. Contudo, também possibilitam uma crítica radical por apresentarem o sofrimento e a opressão como males causados por instituições que precisam ser reconstruídas. (KELLNER, 2001:166)

O musical de sucesso na Broadway, que atualizou e resignificou o te- mor e a suspeita nas relações de classe, sugerindo uma degeneração bestializada e incontrolável, comprometendo o perfeito funcionamento da sociedade, inspirou em 2007 a adaptação livre do teatro para o cinema.

Com parcimônia, para não cair no maniqueísmo, e sem pudor, para não negligenciar fatores que tenham alastramento no inconsciente coletivo, é precioso admitir que desde meados do ano 2000, sob o comando conservador e republicano de Gerge W. Bush, os EUA lidava com um quadro financeiro que gerava desconfianças internas e externas. Sem dar crédito para um grande atentado ${ }^{2}$, apenas em 2008 a insustentável conjuntura financeira, promovida por um liberalismo exacerbado, foi assumida como crise.

Os cidadãos norte americanos, ao longo de uma década decantavam em produções cinematográficas, de enorme popularidade, as angústias, frustrações e preconceitos, de modo a recompor a honra, glória, superação e civismo na luta e bravura. Com significativa variedade e possibilidades múltiplas de interpretações, constam entre as produções de êxito na crítica especializada filmes ${ }^{3}$ como Erin Brockovich, Gladiador, Uma mente brilhante, Dia de Treinamento, A última ceia, Sobre Meninos e Lobos, 21 gramas, Menina de Ouro, Crash - No Limite, Munique, O Segredo de Brokeback Mountain, Pequena Miss Sunshine e À Procura da Felicidade.

Tim Burton, cineasta norte americano, famoso por dirigir filmes que oscilam entre o horror e a comédia, fez uma releitura da história inglesa no contexto acima citado. Recompôs Londres Vitoriana em seu peculiar estilo cianótico e sombrio, com personagens caricatos, cenários e figurinos exdrúxulos, entremeando as partes da história com as músicas aproveitadas da versão teatral. 
Não obstante aos julgamentos de que produtos culturais são de melhor ou pior qualidade, dedicados a um público de maior ou menor capacidade de interlocução, e demais julgamentos que de certo variam bastante conforme o período e lugar, a versão cinematográfica da história "O barbeiro demoníaco da rua Fleet" será neste artigo privilegiada.

Todas as formas da história são eloquentes e eficientes para fazer pensar, para estimular leituras do social, no entanto, com o texto o receptor atua no sentido de imaginar os personagens, figurinos e cenários e tudo o mais que substancia a história. No teatro são dados por inteiro as imagens dos personagens e figurino, e parcialmente o cenário. Já no cinema o visual é completo, sugerindo um leque ampliado de elementos e detalhes em enquadramentos, desde os personagens, figurinos, cenários e até sons, para que o receptor possa se afetar, se envolver e refletir.

\section{Dimensão Semiológica}

Ao propor uma análise de um filme a intenção é a de guiar uma leitura, uma interpretação que confie nesta referência muito além de um produto de entretenimento ou numa fiel reprodução da realidade. É investir nas potencialidades semiológicas, na capacidade de criar narrativas e linguagens, tomando o espectador não como um exclusivo receptor, mas com um ativo interlocutor, um produtor de significados.

Um filme é um produto e é um fato. Um produto na medida em que não se descola de um sistema cujas dinâmicas e regras apontam para a produção, embora a produção não seja um fim por si. E um fato na medida em que é um registro que emana de uma conjuntura específica, com horizontes e limites condizentes ao perí- odo que é produzido, mesmo quando em referência imaginativa de um período que passou, de um período presente ou de um período futuro.

Um filme é então um produto cuja existência, relevância e circularidade está condicionada a dialogias. As interpretações e percepções sobre este produto cultural pairam, portanto, na suposta contradição entre o individual e o coletivo, e vão desde as de origem sinestésica até as legadas de diversas áreas do conhecimento como a filosofia, sociologia, antropologia, história, geografia, biologia e outras. Assim sendo, as analogias, conotações ou denotações expressas nesse texto não têm o objetivo de expressar com exatidão a mensagem que o produtor teve a intenção de projetar no filme, tampouco produzir uma verdade holística. Trata-se de um exercício que toma um produto como ponte para refletir sobre a relação entre a sociedade e a estrutura urbana, revelando matizes de um período, reproduzidas em outro.

A partir da concepção ideal de um sistema, ou um conjunto de elementos em relação, a cidade e a sociedade são abordadas, sem uma predeterminação de quem contém ou quem está contido. Neles coexistem cores, odores, formas, saberes, pessoas, objetos, história, técnicas, comportamentos e diversos outros elementos.

A abertura do filme é efusiva, e o olhar do espectador é conduzido pela alto, em ritmo acelerado, pela noturna cidade, onde são vistos os contornos de prédios e chaminés de fábricas, até descer e escorrer por labirintos sombrios. Nessa espécie de dança por entre as artérias da cidade desliza-se pelo subterrâneo, a parte escondida, a parte infame. No subterrâneo percorre-se dos fornos para o esgoto, passando por uma fábrica, mostrando caminhos por onde o escarlate do sangue contrasta e lubrifica engrenagens acinzentadas ${ }^{4}$. 
Eis a síntese da abertura, um passeio pelo que se exibe e o que se esconde na cidade, na noite onde se reproduz o imaginário e temível, a estrutura e a superestrutura, a cidade como um organismo, os contrastes, e o sangue como lubrificante das engrenagens de um sistema.

As imagens da estrutura, superestrutura e os contrastes da abertura podem ser lidos a partir das abordagens de Estado e Política em Marx. A estrutura corresponde as forças produtivas e relações sociais de produção que constituem a base econômica, determinantes na produção da vida social. E a vida social, a qual Marx denomina superestrutura, seria composta pelas relações de um conjunto de elementos, tais como ideologia, Estado, política, religião, jurisprudência, instituições e outras instâncias voltadas para a organização social.

"Na produção social da sua vida, os homens contraem determinadas relações necessárias e independentes da sua vontade, relações de produção que correspondem a uma determinada fase de desenvolvimento das suas forças produtivas materiais. $\mathrm{O}$ conjunto dessas relações de produção forma a estrutura econômica da sociedade, a base real sobre a qual se levanta a superestrutura jurídica e política e à qual correspondem determinadas formas de consciência social. O modo de produção da vida material condiciona o processo da vida social, política e espiritual em geral". (MARX, 1859: Prefácio à Contribuição à Crítica da Economia Política).

Já a circulação do sangue pela cidade é uma consubstanciação de saberes, entre as descobertas cientificas sobre o funcionamento do corpo humano e as formas de conceber as cidades, numa perspectiva urbanística. Sennet (2003), ao produzir uma investigação da relação entre o corpo e o desenvolvimento das cidades, favorece a compreensão da lógica científica adaptando-se ao planejamento urbano:

A revolução de Harvey favoreceu mudanças de expectativas e planos urbanísticos em todo o mundo. Suas descobertas sobre a circulação do sangue e a respiração levaram a novas idéias a respeito da saúde pública. No lluminismo do século XVIII, elas começaram a ser aplicadas aos centros urbanos. Construtores e reformadores passaram a dar maior ênfase a tudo que facilitasse a liberdade do trânsito das pessoas e seu consumo de oxigênio, imaginando uma cidade de artérias e veias contínuas, através das quais os habitantes pudessem se transportar tais quais hemácias e leucócitos no plasma saudável. A revolução médica parecia ter operado a troca de moralidade por saúde - e os engenheiros sociais estabelecido a identidade entre saúde e a locomoção/ circulação. Estava criado um novo arquétipo da felicidade humana. (SENNET, 2003; 214)

Fechada a abertura, na primeira cena do filme um navio rasga a névoa londrina. Um marinheiro embarcado canta que já viajou todo o mundo, mas que não há lugar como Londres. Benjamim Barker, em resposta, cantarola que o marinheiro é muito jovem e até então a vida fora com ele gentil, mas confirma que não há lugar como Londres. Todavia, sustenta que em Londres a beleza é corrompida, que é um buraco no mundo onde a moral não vale o que um porco poderia cuspir. E no topo desse buraco chamado Londres ficam uns poucos privilegiados que zombam dos outros vermes como se estivessem em um zoológico vil, transformando então a beleza em corrupção e ganância.

O protagonista trás na ação e no discurso musical algumas informações. $A$ 
chegada de barco pelo rio Tâmisa é uma ênfase à concepção de que as grandes cidades mundiais se desenvolveram por conta de suas localizações e condições pluviais, as quais seriam sine qua non para a quantidade e qualidade de relações com o mundo, fosse em prol do enriquecimento promovido pelas trocas comerciais, fosse em prol do desenvolvimento de saberes e técnicas impulsionado pela difusão do conhecimento.

No barco, cuja paisagem ao fundo é a noite de Londres iluminada por candeeiros, o personagem explica ser um degredado, retornando após quinze anos na Austrália, local para onde foi injustamente mandado. Eis as colônias a expansão e expressão de um império virtuoso pelo mundo, locais para onde são excretados o que não interessa à metrópole. $\mathrm{E}$ a frase "Não há lugar como Londres" exalta para cada qual dos personagens o quanto esta cidade é distinta, estimulando a imagem e o imaginário da dita distinção, instigando os ouvintes a embarcarem em suas histórias. Há então duas Londres, uma das possibilidades, encenada pelo jovem marinheiro, e a outra, maior, é a da frustração, objeto de reparação, protagonizada por Benjamin Barker, que para empreender seu objetivo assume a identidade de Sweeney Todd.

Na sequência, o personagem canta, conta e passeia pela história que o trás de volta para Londres. Um recurso técnico visual é usado a fim de localizar o tempo em que o narrador está, e o tempo passado. O agora é escuro, numa fotografia puxada para o tom de chumbo, e o passado é visto brilhante e colorido.

Benjamin Barker era um homem ingênuo, casado com uma linda mulher, com a qual tinha uma filha. Um dia a beleza de sua esposa foi vista e desejada por um homem poderoso, ligado a lei, o Juiz Turpin. Esse homem da lei usou de sua influência para então separar o casal, exilando de Barker injustamente na Austrália. Eis o motivo do retorno de Benjamin Barker, a vingança.

\section{Tensões de uma nova ordem}

As imagens da cidade revelam uma quantidade estonteante de estímulos. Em primeiro plano se exibe a materialidade, a concretude, a estrutura física de uma cidade que cresce às margens do Tâmisa. Esta estrutura em uso, na atuação dos personagens, pode ser lida de modo a revelar a superestrutura, as normas, as crenças, a cultura e demais elementos que produzem a vida social, a esfera pública.

O espaço como abstração, o lugar como um espaço em que se imprime significados, e o território como o lugar definido por relações de poder. Essas são noções podem ser articuladas de modo eficientes para orientar o olhar para as formas de apropriação espaço via relações de poder.

Benjamin Barker passeia pelas ruas de Londres, fazendo um reconhecimento do lugar, em parte na materialidade, em parte nos afetos. Chega a uma rua de comércio e entra numa decrépita loja de tortas, imunda e conhecida por produzir as piores tortas de toda a cidade. A dona da loja oferece uma torta e conta sua história.

Explica ao desconhecido que sua loja fabrica as piores tortas da cidade, mas que um dia fora a barbearia de um homem, que caiu em desgraça quando sua família fora desfeita por conta da paixão do Juiz Turpin.

Lovett, a dona da loja, conduziu Sweeney Todd ao sobrado para contar mais e mais da história que a fascina, e mostrar mais elementos dessa história do 
lugar. Ao mostrar as janelas e objetos, o estranho se estremece com a história e confessa ser o barbeiro, sedento por vingança. Seduzida pela história e pelo homem, senhorita Lovett assume uma espécie de sociedade com Benjamin Barker, fundada na cumplicidade e confiança.

O acordo de sentimento, confiança, palavra, assenta-se como a relação social fundamental para que Sweeney Todd empreenda seu objetivo. E simultaneamente se coloca como um contraponto da ordem então vigente em Londres: a lei, a racionalidade, a secularidade, o contrato, a ordem.

$O$ ideal da ordem transfigura-se como a regra que informa o perfeito funcionamento de um organismo. Quaisquer desvios dessa ordem são identificados como anomalias, vícios, descontroles. A sujeira e decrepitude na estrutura física que abriga a senhorita Lovett e passa a ser o local ideal para os planos de Sweeney Todd é uma associação entre a degradação do lugar e a degradação moral. Desta associação Sontag (2007) esclarece:

"Doenças epidêmicas eram uma figura de linguagem comum para designar a desordem social. Da palavra inglesa pestilent, cujo sentido figurado, segundo Oxford English Dictionary, é "ofensivo à religião, à moral ou à paz pública - 1513"; e pestilential, que significa "moralmente pernicioso ou deletério - 1531". Os sentimentos sobre o mal são projetados numa doença. E a doença (tão enriquecida de sentidos) é projetada sobre o mundo, (SONTAG, 2007: 53-54)

A negligência aos critérios sanitários é a reiteração de que o ambiente "doentio" abriga indivíduos "doentes", ou mais precisamente nocivos ao perfeito funcionamento do organismo social. Além da alusão de que o ambiente influencia o indivíduo, a estrutura física é composta também por uma história, por uma ordem de significação. Correlatamente, a degeneração do indivíduo tem uma origem na subjetivação, na forma como o indivíduo significa o mundo que o rodeia, e a maneira como se coloca perante esse mundo. Entra em cena a inclinação para as explicações psicológicas dos comportamentos desviantes. Esta assinala a percepção do desvio associado a estados mentais que induzem o indivíduo a comportamentos desviantes. E assim sendo o desviante está mais para a cura do que para a punição.

Investindo na vertente da doença psíquica, a cura de um trauma passa pela catarse. Na psicanálise a catarse é a libertação de emoções quando se coloca no plano da consciência as recordações recalcadas. Já em termos filosóficos, para Aristóteles a catarse seria a purificação sentida pelos espectadores durante e depois de representações dramáticas. Eis que é a espetacularização dramática, a ostentação do suplício do seu ofensor, o objetivo levado a cabo por Benjamim Barker, Sweeney Todd.

Entre o restabelecimento psicológico por uma ofensa moral e a punição como recurso que auxilia a normatização do comportamento social, Barker está para a defesa da honra via suplício, enquanto o juiz Turpin para o poder da lei como uma entidade suprema. Neste duelo a instituição que tenta ordenar a sociedade é derrotada, já que Benjamin Barker é bem sucedido. Mas o triunfo de Barker é curto, afinal, uma criança, a esperança, o futuro, aniquila o demônio, pondo fim à saga.

Foucault (2004), ao empreender uma análise da esfera do poder atenta à dinâmica das formas punitivas, apresenta questões relevantes para a leitura 
do filme, indicando o quanto a ação de Barker na ordem pessoal pode ser uma expiação coletiva:

Desaparece, destarte, em princípios do século XIX, o grande espetáculo da punição física: o corpo supliciado é escamoteado; exclui-se do castigo a encenação da dor. Penetramos na época da sobriedade punitiva. Podemos considerar o desaparecimento dos suplícios como um objetivo mais ou menos alcançado, no período compreendido entre 1830 e 1848. Claro, tal afirmação em termos globais deve ser bem entendida. Primeiro, as transformações não se fazem em conjunto nem de acordo com um único processo. Houve atrasos. Paradoxalmente, a Inglaterra foi um dos países mais reacionários ao cancelamento dos suplícios: talvez por causa da função de modelo que a instituição do júri, o processo público e o respeito ao habeas-corpus haviam dado à sua justiça criminal; (FOUCAULT, 2004: 6-17)

Percebe-se no filme que o suplício enquanto forma punitiva ainda não se apagara do inconsciente social na Inglaterra. Assim, é posto na história como a finalidade maior do ofendido, em uma trama em que critérios morais se entrelaçam com a dimensão jurídica, em que a violência física se contrapõe com perversas regras de civilidade, e que a emoção não invalida a razão, na medida em que tanto o juiz usa a razão para alcançar seu objetivo afetivo, quanto Barker planeja e ensaia a sua vingança, no afã da maior satisfação moral possível.

O protesto contra os suplícios é encontrado em toda parte na segunda metade do século XVIII: entre os filósofos e teóricos do direito; entre juristas, magistrados, parlamentares; nos chaiers de doléances e entre os legisladores das assembléias. É preciso punir de outro modo: eliminar essa confrontação física entre soberano e condenado; esse conflito frontal entre a vingança do príncipe e a cólera contida do povo, por intermédio do supliciado e do carrasco. O suplício tornou-se rapidamente intolerável. Revoltante, visto da perspectiva do povo, onde ele revela a tirania, o excesso, a sede de vingança e o "cruel prazer de punir". Vergonhoso, considerado da perspectiva da vítima, reduzida ao desespero e da qual ainda se espera que bendiga "o céu e seus juizes por quem parece abandonada". Perigoso de qualquer modo, pelo apoio que nele encontram, uma contra a outra, a violência do rei e a do povo. Como se o poder soberano não visse, nessa emulação de atrocidades, um desafio que ele mesmo lança e que poderá ser aceito um dia: acostumado a "ver correr sangue", o povo aprende rápido que "só pode se vingar com sangue". (FOUCAULT, 2004, 62-63)

O que é expresso na superestrutura encenada no filme é, portanto, uma espécie de crise entre uma ordem que se instaura na Londres industrializada e adensada, que força a relação entre classes desiguais, e a relutância de uma ordem anterior, em que pese os critérios morais.

\section{Considerações}

Ao sabor de uma narrativa e estética peculiar, de um renomado diretor de cinema, Tim Burton, numa representação atual de um espaço urbano correspondente a um período passado, a história "O Barbeiro Demoníaco da Rua Fleet" é apresentada. Este filme é um produto cultural eloquente para refletir o período de intensas transformações da estrutura urbana e das relações sociais da Inglaterra Vitoriana. Tomando por sua trajetória, pri- 
meiro como parte uma história de uma coleção, depois como musical teatral, e por fim como um filme musical, da Inglaterra Vitoriana para os EUA, primeiro na era Reagan e depois na crise financeira no período do governo Bush, as alegorias e sensibilidades foram criadas em um contexto e adaptadas, atualizadas, a outro.

Como produto cultural institui em qualquer tempo o descompassos entre 0 ritmo de desenvolvimento do urbano, condizentes ao sistema de produção capitalista, e as formas de produzir o social, percepções estas enunciadas por Karl Marx ao desenvolver uma teoria política em sociedades cujo funcionamento é informado pelo sistema capitalista de produção.

Entra contraste no filme classes sociais, um trabalhador de ofício manual e um homem de letras, em uma contenda entre a norma jurídica e a norma moral. Insinua o perigo, o desconforto, a desconfiança, do convívio próximo entre classes distintas. Assinala ainda o quanto o ambiente urbano, na analogia de um corpo, está sujeito a defeitos, vícios. Nesta perspectiva Foucault é precioso ao observar o desenvolvimento das formas punitivas, delineando a trajetória da esfera do poder, partindo da noção espetacularizada dos suplícios para um aparato arquitetônico, técnico, jurídico e burocrático para lidar com as formas punitivas.

\section{Bibliografia}

CABRERA, Julio. O cinema pensa: Uma introdução à filosofia através dos filmes. Rio de Janeiro: Ed. Rocco, 2006.

CASTRO, Iná Elias de; GOMES, Paulo César da Costa; CORRÊA, Roberto Lobato. (org'.s). Geografia: conceitos e temas. Rio de Janeiro: Bertrand Brasil, 1995. p. 15-47; 77-116

DELEUZE, Gilles. A imagem-tempo. São Paulo: Ed. Brasiliense, 2007.
FOUCAULT, Michel. Vigiar e Punir: nascimento da prisão. Petrópolis: Ed. Vozes, 2004.

KELLNER, Douglas. A cultura da mídia - estudos culturais: identidade e política entre o moderno e o pós moderno. Bauru, EDUSC, 2001.

MANGUEL, Alberto. Lendo imagens. São Paulo: Companhia das Letras, 2008.

MARX, Karl. Contribuição para a crítica da teoria política, 1859.

METZ, Christian. A significação no cinema. São Paulo: Ed. Perspectiva, 2010.

RIVERA, Tania. Cinema, imagem e psicanálise. Rio de Janeiro: Jorge Zahar Ed., 2008.

ROSENFELD, Anatol. Cinema: arte \& indústria. São Paulo: Ed. Perspectiva, 2009.

SONTAG, Susan. Doença como metáfora: AIDS e suas metáforas. São Paulo: Companhia das Letras, 2007.

1 Graduada em Comunicação Social (FACHA) e em Ciências Sociais (IFCS/UFRJ), Mestre e Doutoranda em Planejamento Urbano e Regional (IPPUR/UFRJ).

2 Em 11 de Setembro de 2001 o coração financeiro dos EUA foi atingido por dois aviões comerciais, que colidiram e derrubaram as torres gêmeas do World Trade Center.

3 Toma-se aqui alguns dos filmes que foram indicados e/ou premiados pelo Oscar, das edições de 2000 a 2007. Muitos outros filmes foram produzidos nesse período, todavia, a indicação da academia confere relevância e expressão mundial para algumas produções. E aguça esta suposta credibilidade da premiações a noção de que a academia foi criada por motivos específicos, os quais influenciam suas decições e escolhas, embora pareça aceitável que apontem objetivamente para o prestígio de bons trabalhos.

4 Parodiando a cena clássica de "Tempos Modernos" em que Chaplin entra na máquina. 